\title{
23. INTERMEDIATE AND LATE DIAGENETIC TETRAPYRROLE PIGMENTS, LEG 41: CAPE VERDE RISE AND BASIN
}

\author{
E.W. Baker, S.E. Palmer, and W.Y. Huang \\ Department of Chemistry, Northeast Louisiana University, Monroe, Louisiana
}

\section{INTRODUCTION}

The already considerable interest on the part of organic geochemists in sediments of the Cape Verde Rise and Basin was increased by the discovery of an igneous intrusion during drilling at Site 368. At 957 meters in organic-carbon-rich Late Cretaceous sediments a diabase sill of Miocene age, 13.5 meters thick, was penetrated. The products resulting from thermal metamorphism as well as those with a normal thermal history could be studied and contrasted. In addition, the normal marine sediments from this section were studied and compared with previous studies.

Sediments of Pleistocene to Lower Cretaceous at subbottom depths of 10 to 880 meters were found to contain either chlorins or a mixture of chlorins and free-base porphyrins. The nature of these pigments is indicative of intermediate stages of normal organic diagenesis. Upper Cretaceous sediments recovered at 943 to 979 meters depth contain only nickel and vanadyl porphyrins. These sediments have undergone short-term thermal metamorphism and the characteristics of the metalloporphyrins isolated from these sediments dramatically display this effect. The first occurrence of deep-sea petroporphyrins other than at Challenger Knoll (Baker, 1969) is noteworthy. In addition, hydrocarbon characteristics and vitrinite reflectance values systematically reflect the effect of induced thermal maturation. The data obtained from extracts of these thermally stressed sediments strongly support the source rock potential of Cretaceous black shales, given sufficient burial. ${ }^{1}$

The possible mode of petroporphyrin formation is presented. Diagenetic reactions of metalloporphyrins are segregated according to temperature and then used to construct a plausible thermal gradient in the vicinity of the diabase sill.

\section{EXPERIMENTAL}

Methods used for isolation, purification, and identification of geopigments are detailed in the Leg 40 Initial Report (Baker et al., in press). The same procedures were applied to these samples. However, owing to aromatic hydrocarbons accompanying the metalloporphyrins, liquid-liquid extraction using

\footnotetext{
'These data were obtained from selected Site 368 samples and provided by W.G. Dow of the Superior Oil Company.
}

methylsulfoxide:heptane was required as an additional purification step.

UV-visible spectra (Table 1) were recorded using a Beckman ACTA CIII ultraviolet visible scanning spectrophotometer. Mass spectrometric analyses were made using a DuPont 491-BR mass spectrometer equipped with a solid sample probe inlet system. Probe temperatures ranged from $225^{\circ}$ to $240^{\circ} \mathrm{C}$ for the free base porphyrins, $245^{\circ}$ to $280^{\circ} \mathrm{C}$ for nickel porphyrins, and $230^{\circ}$ to $240^{\circ} \mathrm{C}$ for vanadyl porphyrins. Source temperatures were kept $5^{\circ}-10^{\circ} \mathrm{C}$ above that of the probe.

Porphyrin mass spectrometric data (Table 2) are presented as normalized $\mathrm{m} / \mathrm{e}$ peak intensities. Peak intensities for free-base, vanadyl, and nickel porphyrins of the DPEP series were used directly in these calculations. However, data obtained for nickel porphyrins of the etio series were corrected for the $\mathrm{Ni}^{60}$ isotope contribution from the corresponding nickel DPEP (isotopic abundance of $\mathrm{Ni}^{58}=67.8 \%$; $\mathrm{Ni}^{60}=$ $26.2 \%$; ratio of $\mathrm{Ni}^{58}$ to $\mathrm{Ni}^{60}=0.38$ ).

Molecular weight distribution parameters based on the data in Table 2 are given in Table 3. For each porphyrin sample, the DPEP/etio ratio, weighted average mass, and band width have been calculated.

Mass spectrometric analysis of chlorins was limited to two sample extracts (369A-43 and 367-19). In these cases, the source temperature was set at $290^{\circ} \mathrm{C}$; the unheated probe inserted, and the mass spectrum recorded immediately. This particular method only allows a glimpse of the composition of the chlorin mixture but no opportunity for repeated scans. For this reason, we have limited the mass spectrometric analyses of chlorin fractions until such time as a procedure is developed in which more information can be obtained.

\section{RESULTS}

\section{Chlorins}

Younger sediments of Pleistocene, Pliocene, and Miocene age contained only small amounts of chlorins (range $=$ undetectable level to $0.07 \mu \mathrm{g}$ pigment $/ \mathrm{g}$ of sediment). Extracts of Eocene sediment contained 0.4 to $1.3 \mu \mathrm{g} / \mathrm{g}$ of chlorin. Cretaceous sediments at 400 to 880 meters depth of burial yielded 0.3 to $8.2 \mu \mathrm{g} / \mathrm{g}$ of pigment, suggesting higher productivity and/or a higher rate of accumulation during this geologic period. No trend in concentration was observed (Table 1).

Generally speaking, the chlorins are characterized as having short wavelength red bands (656 to $659 \mathrm{~nm}$ ) and 
TABLE 1

Tetrapyrrole Pigments Isolated From Leg 41 Core Samples

\begin{tabular}{|c|c|c|c|c|c|c|c|c|c|c|c|c|c|}
\hline $\begin{array}{c}\text { Sample } \\
\text { (Interval in } \mathrm{cm} \text { ) }\end{array}$ & Geologic Age $^{a}$ & $\begin{array}{l}\text { Lithologic } \\
\text { Description }\end{array}$ & $\begin{array}{l}\text { Depth of } \\
\text { Burial }^{\mathrm{a}} \\
\text { (m) }\end{array}$ & $\begin{array}{l}\text { Organic } \\
\text { Carbon } \\
\text { (wt \%) }\end{array}$ & $\begin{array}{c}\text { Individual } \\
\text { Yield } \\
(\mu \mathrm{g} / \mathrm{g})\end{array}$ & & & UV-Visible & $\begin{aligned} \text { Absorp } \\
(\mathrm{nm})\end{aligned}$ & ion Spectra & & & $\begin{array}{c}\text { Pigment } \\
\text { Type }\end{array}$ \\
\hline $367-19-4$ & $\begin{array}{l}\text { Middle } \\
\text { Cretaceous }\end{array}$ & $\begin{array}{l}\text { calc. } \\
\text { bk. shale }\end{array}$ & 650 & 6.5 & $\begin{array}{r}34.9 \\
8.2\end{array}$ & 399 & 500 & 527 & 568 & 617 & 594 & 658 & $\begin{array}{l}\text { Chlorin } \\
\text { Free base porphyrin }\end{array}$ \\
\hline $368-3-5$ & $\begin{array}{l}\text { Pleistocene } \\
\text { Pliocene }\end{array}$ & calc. mud & 50 & 0.11 & 0.004 & 395 & & & & & 595 & 655 & Chlorin \\
\hline $368-15-3$ & $\begin{array}{l}\text { Middle } \\
\text { Miocene }\end{array}$ & $\begin{array}{l}\text { sl. cal. } \\
\text { blue-gray mud }\end{array}$ & 250 & 0.04 & none & & & & & & & & \\
\hline $\begin{array}{l}368-43-2 \\
130-135\end{array}$ & $\begin{array}{l}\text { Early } \\
\text { Eocene }\end{array}$ & gray shale & 610 & 1.03 & c & & & & & & & & Chlorin (?) \\
\hline $\begin{array}{l}368-58-4 \\
130-135\end{array}$ & $\begin{array}{l}\text { Late } \\
\text { Cretaceous }\end{array}$ & blue mud & 943 & 0.30 & 0.05 & 394 & & 513 & 552 & & & & Nickel porphyrin \\
\hline $\begin{array}{l}368-59-3 \\
98-106\end{array}$ & $\begin{array}{l}\text { Late } \\
\text { Cretaceous }\end{array}$ & blue mud & 950 & & 0.1 & 394 & & 513 & 552 & & & & Nickel porphyrin \\
\hline $\begin{array}{l}368-60-2 \\
55-63\end{array}$ & $\begin{array}{l}\text { Late } \\
\text { Cretaceous }\end{array}$ & blk. shale & 952 & & none & & & & & & & & \\
\hline $\begin{array}{l}368-60-3 \\
25-33\end{array}$ & $\begin{array}{l}\text { Late } \\
\text { Cretaceous }\end{array}$ & blk. shale & 953 & & none & & & & & & & & \\
\hline $\begin{array}{l}368-60-4, \\
55-63\end{array}$ & $\begin{array}{l}\text { Late } \\
\text { Cretaceous }\end{array}$ & $\begin{array}{l}\text { sl. calc. } \\
\text { blk. shale }\end{array}$ & 955 & & none & & & & & & & & \\
\hline $\begin{array}{l}368-60-5 \\
28-36\end{array}$ & $\begin{array}{l}\text { Late } \\
\text { Cretaceous }\end{array}$ & blk. shale & 956 & & none & & & & & & & & \\
\hline $\begin{array}{l}368-62-3, \\
18-26\end{array}$ & $\begin{array}{l}\text { Late } \\
\text { Cretaceous }\end{array}$ & $\begin{array}{l}\text { sl. calc. } \\
\text { brown shale }\end{array}$ & 971 & & none & & & & & & & & \\
\hline $\begin{array}{l}368-62-3 . \\
72-80\end{array}$ & $\begin{array}{l}\text { Late } \\
\text { Cretaceous }\end{array}$ & $\begin{array}{l}\text { sl. calc. } \\
\text { black shale }\end{array}$ & 971 & & none & & & & & & & & \\
\hline $\begin{array}{l}368-62-4 \\
44-52\end{array}$ & $\begin{array}{l}\text { Late } \\
\text { Cretaceous }\end{array}$ & black shale & 972 & & none & & & & & & & & \\
\hline $\begin{array}{l}368-62-4 \\
118-126\end{array}$ & $\begin{array}{l}\text { Late } \\
\text { Cretaceous }\end{array}$ & black shale & 973 & & $\begin{array}{l}0.2 \\
0.4\end{array}$ & $\begin{array}{l}394 \\
407\end{array}$ & & 532 & 552 & 571 & & & $\begin{array}{l}\text { Nickel porphyrin } \\
\text { Vanadyl porphyrin }\end{array}$ \\
\hline $\begin{array}{l}368-63-1 \\
68-76\end{array}$ & $\begin{array}{l}\text { Late } \\
\text { Cretaceous }\end{array}$ & $\begin{array}{l}\text { sl. calc. } \\
\text { black shale }\end{array}$ & 974 & & $\begin{array}{l}4.3 \\
2.9\end{array}$ & $\begin{array}{l}394 \\
407\end{array}$ & & 532 & 552 & 571 & & & $\begin{array}{l}\text { Nickel porphyrin } \\
\text { Vanadyl porphyrin }\end{array}$ \\
\hline $\begin{array}{l}368-63-2 \\
20-21\end{array}$ & $\begin{array}{l}\text { Late } \\
\text { Cretaceous }\end{array}$ & $\begin{array}{l}\text { calc. black } \\
\text { shale }\end{array}$ & 975 & & $\begin{array}{l}1.7 \\
2.5\end{array}$ & $\begin{array}{l}394 \\
407\end{array}$ & & 532 & 552 & 571 & . & & $\begin{array}{l}\text { Nickel porphyrin } \\
\text { Vanadyl porphyrin }\end{array}$ \\
\hline $\begin{array}{l}368-63-3 \\
141-144\end{array}$ & $\begin{array}{l}\text { Late } \\
\text { Cretaceous }\end{array}$ & $\begin{array}{l}\text { sl. calc. } \\
\text { blue mud }\end{array}$ & 978 & 1.43 & $\begin{array}{l}0.3 \\
0.2\end{array}$ & $\begin{array}{l}394 \\
407\end{array}$ & & 532 & 552 & 571 & & & $\begin{array}{l}\text { Nickel porphyrin } \\
\text { Vanadyl porphyrin }\end{array}$ \\
\hline $\begin{array}{l}368-63-4 \\
90-98\end{array}$ & $\begin{array}{l}\text { Late } \\
\text { Cretaceous }\end{array}$ & $\begin{array}{l}\text { calc. blk. } \\
\text { shale }\end{array}$ & 979 & & 3.5 & 394 & & 513 & 552 & & & & Nickel porphyrin \\
\hline $\begin{array}{l}369-2-5 \\
130-135\end{array}$ & Pliocene & $\begin{array}{l}\text { gray lime } \\
\text { mud }\end{array}$ & 10 & 0.42 & 0.006 & 395 & & & & & 595 & 657 & Chlorin \\
\hline
\end{tabular}




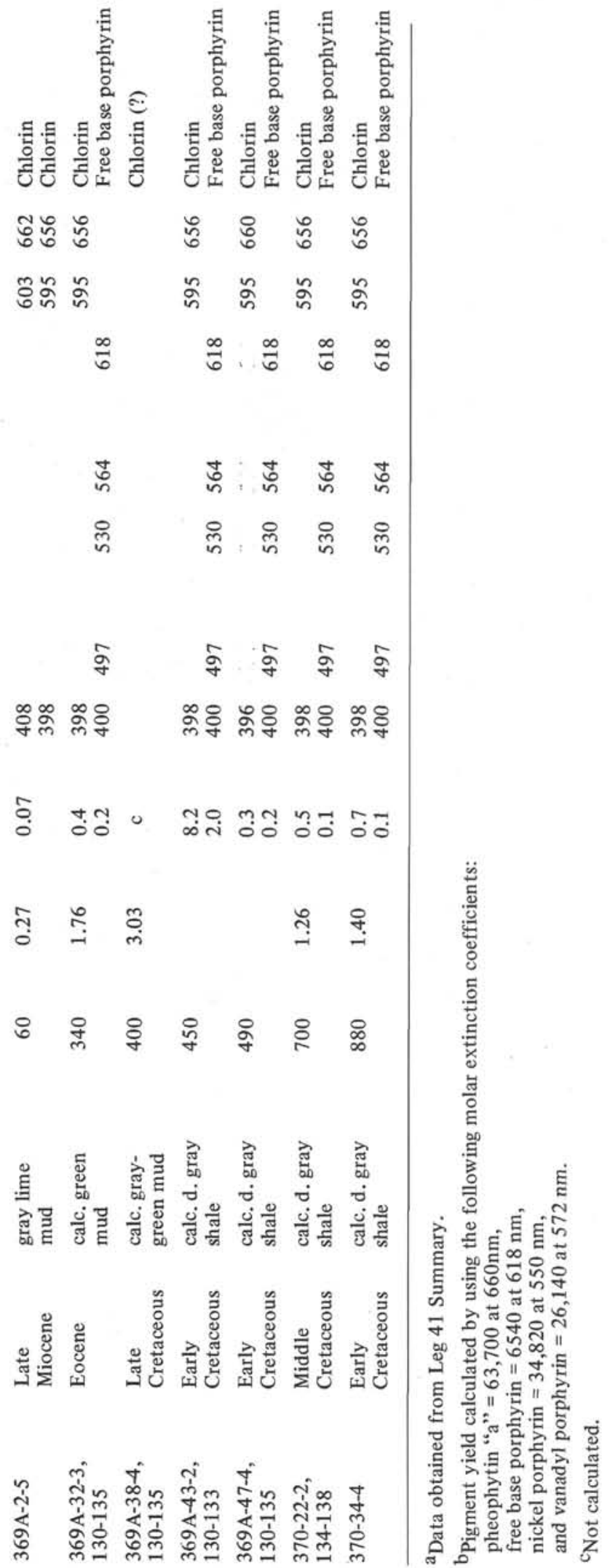

Soret bands ( 398 to $399 \mathrm{~nm}$ ). These data typify chlorins of older sediments (Pliocene through Cretaceous) and contrast with chlorins isolated from Pleistocene sediments (red band $=661 \mathrm{~nm}$, Soret band $=407 \mathrm{~nm}$ ). These differences are discussed at greater length in the Initial Reports of Leg 40 and Leg 44 (Baker et al. in press).

A fraction of a chlorin sample from 369A-43-2, isolated by acid extraction $(3 \mathrm{~N} \mathrm{HCl}=9.7 \% \mathrm{w} / \mathrm{v})$ was selected for study. The low $\mathrm{HCl}$ number (ca. 10) is indicative of the degree of reduction in line with expectations for chlorins isolated from Lower Cretaceous sediments. The UV-visible spectrum is characterized by shorter wavelength red bands (656-659 $\mathrm{nm}$ ) which can result from increasing reduction of ring conjugating groups, such as the 9-keto and 2-vinyl substitutents (Smith and Baker, 1974).

From mass spectrometric analysis of this chlorin fraction, molecular weight values of $872,856,858$, and 830 were obtained, suggesting that the phytol side chain was still intact in these relatively old chlorins. These data support similar earlier reports (Baker and Smith, 1973). The major molecular weights observed were 856 , 858 , and 830 ; this finding is in line with the geologic age of the enclosing sediments. An increase in these lower molecular weights relative to 872 with respect to increasing depth of burial was previously reported for Pleistocene sediments.

Since abundant chlorins were also present in Section 367-19-4 of Mid Cretaceous age, mass spectrometric analyses were made. The spectrum obtained for this fraction was very similar to that of $369 \mathrm{~A}-43-2$.

\section{Free Base Porphyrins}

Free base DPEP-type porphyrins were found with chlorins in sediment samples of Eocene and Cretaceous age (Table 1). Previously, free base porphyrins have been reported in Pleistocene, Pliocene (Baker et al., in press), Miocene (Baker and Smith, 1975; and Smith and Baker, 1974), and Cretaceous (Baker et al., in press) sediments. In this particular area, however, samples younger than Eocene were devoid of free base porphyrins.

The mass spectrometric data and parameters of four examples of these pigments are given in Tables 2 and 3. The major molecular weight species is 476 , equivalent to DPEP itself; lower molecular weight members (462, $448,434,420$, and occasionally 406) are present in lesser amounts (Table 2).

Band widths $(\sigma)$ and average molecular weights $(X)$ show little variation between the four samples analyzed, with Core 369A-32 being an exception by having a lower average mass and slightly wider band width.

\section{Metalloporphyrins}

Late diagenetic geoporphyrins (i.e., petroporphyrins) were obtained from Upper Cretaceous sediments recovered from 973 to 979 meters depth of burial, Site 368 . The occurrence of these products is directly related to igneous activity, resulting in heat-induced diagenetic reactions, namely, dealkylation, isocyclic ring rupture (etio-series generation), and alkylation. Small 
TABLE 2

Mass Spectral Data Obtained for Free Base, Nickel, and Vanadyl Porphyrins From Core Samples

From Sites 357, 368, and 369A (peak intensities are normalized to 100 for the most intense peak)

368-58 Nickel Porphyrin

$\begin{array}{rrrrrrrr}\text { (DPEP series } & 532 & 518 & 504 & 490 & 476 & 462 & \mathrm{~m} / \mathrm{e}\end{array}$

\begin{tabular}{lrrrrrr} 
(etio series) & 534 & 520 & 506 & 492 & 478 & 464 \\
\hline 4 & 5 & 8 & 9 & 7 & 5
\end{tabular}

368-63-1 Nickel Porphyrin

\begin{tabular}{lrrrrr} 
(etio series) & 506 & 492 & 478 & 464 & 450 \\
\hline & 45 & 65 & 87 & 100 & 52
\end{tabular}

368-63-2, Nickel Porphyrin

$20-21 \mathrm{~cm}$

\begin{tabular}{|c|c|c|c|c|c|c|c|c|}
\hline (DPEP series) & 546 & 532 & 518 & 504 & 490 & & & \\
\hline & 25 & 39 & 45 & 39 & 25 & & & \\
\hline (etio series) & 534 & 520 & 506 & 492 & 478 & 464 & 450 & \\
\hline & 16 & 30 & 77 & 100 & 70 & 34 & 16 & \\
\hline
\end{tabular}

Vanadyl Porphyrin

(DPEP series) $583 \quad 569$ 555 541 527 513 499 485

(etio series)

$\begin{array}{rrr}557 & 543 & 529 \\ 18 & 36 & 72\end{array}$

515

$\begin{array}{rr}501 & 478 \\ 100 & 72\end{array}$

473

368-63-2 Nickel Porphyrin $44-52 \mathrm{~cm}$

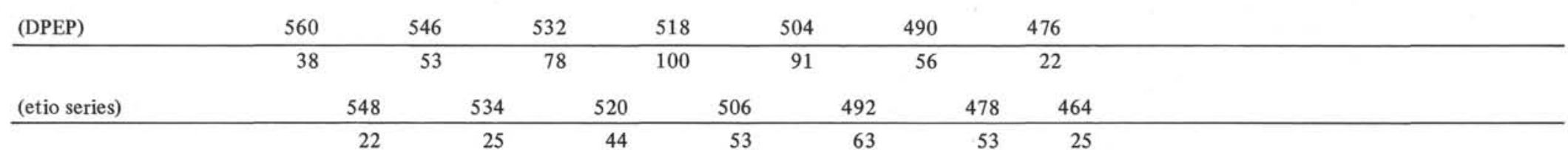

Vanadyl Porphyrin

\begin{tabular}{|c|c|c|c|c|c|c|c|c|c|c|c|c|c|c|}
\hline (DPEP series) & 611 & 597 & & 583 & & 569 & & 555 & 541 & 527 & 513 & 499 & 485 & \\
\hline & 11 & 13 & & 20 & 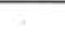 & 30 & . & 66 & 100 & 88 & 54 & 26 & 12 & \\
\hline (etio series) & 599 & & 585 & & 571 & & 557 & 543 & 529 & 515 & 501 & 487 & 473 & 459 \\
\hline & 9 & & 12 & & 12 & & 28 & 42 & 62 & 82 & 68 & 36 & 18 & 9 \\
\hline
\end{tabular}


368-63-3, Nickel Porphyrin

$141-144 \mathrm{~cm}$

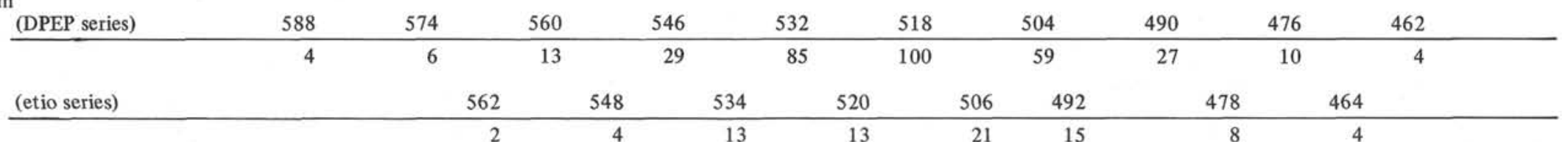

Vanadyl Porphyrin

\begin{tabular}{rrrrrrrrr} 
(DPEP series) & 583 & 569 & 555 & 541 & 527 & 513 & 499 & 485 \\
\hline 2 & 4 & 19 & 100 & 82 & 36 & 10 & 4
\end{tabular}

\begin{tabular}{lrrrrrr} 
(etio series) & 557 & 543 & 529 & 515 & 501 & 487 \\
\hline & 2 & 9 & 8 & 5 & 5 & 3
\end{tabular}

368-63-4 Nickel Porphyrin

\begin{tabular}{lrrrrrr} 
(DPEP series) & 546 & 532 & 518 & 504 & 490 & 476 \\
\hline & 24 & 100 & 84 & 57 & 24 & 16
\end{tabular}

\begin{tabular}{rrrrrrrrr} 
(etio series) & 548 & 534 & 520 & 506 & 492 & 478 & 464 & 450 \\
\hline & 6 & 16 & 16 & 22 & 33 & 22 & 16 & 15
\end{tabular}

367-19 Free base Porphyrin

(DPEP series)

$\begin{array}{rrrrr}476 & 462 & 448 & 434 & 420 \\ 100 & 36 & 18 & 8 & 6\end{array}$

368-27 Free base Porphyrin

\begin{tabular}{lrrrrr} 
(DPEP series) & 476 & 462 & 448 & 434 & 420 \\
\hline & 100 & 51 & 27 & 13 & 10
\end{tabular}

369A-32 Free base Porphyrin

\begin{tabular}{lrrrrrr} 
(DPEP series) & 476 & 462 & 448 & 434 & 420 & 406 \\
\hline & 100 & 63 & 60 & 41 & 34 & 6
\end{tabular}

369A-43 Free base Porphyrin

\begin{tabular}{lrrrrr} 
(DPEP series) & 476 & 462 & 448 & 434 & 420 \\
\hline & 100 & 56 & 27 & 13 & 7
\end{tabular}


TABLE 3

Molecular Weight Distribution Parameters of Free Base, Nickel, and Vanadyl Porphyrins Isolated From Core Samples, Sites 367, 368, and Hole 369A

\begin{tabular}{|c|c|c|c|c|c|c|}
\hline \multirow[b]{2}{*}{ Sample } & \multirow{2}{*}{$\begin{array}{c}\text { Porphyrin } \\
\text { Type }\end{array}$} & \multirow{2}{*}{$\frac{\text { DPEP } \Sigma I^{\mathrm{a}}}{\text { etio } \Sigma I}$} & \multicolumn{2}{|c|}{ Weighted Av. Mass ${ }^{\mathrm{b}}$} & \multicolumn{2}{|c|}{ Band Width ${ }^{\mathrm{c}}$} \\
\hline & & & XDPEP & Xetio & $\sigma$ DPEP & getio \\
\hline $367-19$ & Free base & & 466 & & 15 & \\
\hline $368-27$ & Free base & & 463 & & 16 & \\
\hline $369 \mathrm{~A}-32$ & Free base & & 454 & & 20 & \\
\hline $369 \mathrm{~A}-43$ & Free base & & 464 & & 15 & \\
\hline $368-58$ & Nickel & 7.5 & 505 & 497 & 18 & 21 \\
\hline $368-63-1$ & Nickel & 0 & & 476 & & 18 \\
\hline $368-63-2$, & Nickel & 0.5 & 518 & 492 & 18 & 20 \\
\hline $20-21$ & Vanadyl & 0.5 & 528 & 506 & 25 & 24 \\
\hline $368-63-2$ & Nickel & 1.5 & 519 & 502 & 23 & 24 \\
\hline $45-52$ & Vanadyl & 1.1 & 540 & 521 & 27 & 30 \\
\hline $368-63-3$, & Nickel & 3.5 & 521 & 509 & 22 & 23 \\
\hline $141-144$ & Vanadyl & 7.9 & 532 & 524 & 16 & 20 \\
\hline $368-63-4$ & Nickel & 2.1 & 520 & 495 & 18 & 27 \\
\hline
\end{tabular}

a Obtained from Table 2;1 is mass spectral peak intensity.

${ }^{b}$ Corresponds to the weighted average mass, obtained by $\Sigma 1 M / \Sigma I$ from Table 2 where $M$ is the mass and $I$ is the intensity.

${ }^{\mathrm{c}}$ The band width is given as the standard deviation $(\sigma)$ in mass units, computed according to the formula $\sigma=\Sigma\left(\mathrm{IM}^{2}\right) / \Sigma \mathrm{I}-(\Sigma \mathrm{IM} / \Sigma \mathrm{I})^{2}$, where $\mathrm{I}$ is the intensity and $\mathrm{M}$ the mass, both taken from Table 2.

quantities ( 0.1 to $0.05 \mu \mathrm{g} / \mathrm{g}$ ) of nickel porphyrins were found 7 and 14 meters above the sill. The DPEP to etio ratio was high in Core 368-58 (Tables 2 and 3). Sections from Core 60 were barren, yielding clear extracts. Aromatic hydrocarbons (?) appeared in Sections 3 and 4 of Core 62. Nickel and vanadyl porphyrins were isolated from 368-62-4 and 63-1 only with great difficulty; large amounts of impurities relative to the meager porphyrin content precluded mass spectrometric analysis of extracts from 62-4. However, the nickel porphyrin fraction from 63-1 was analyzed and an interpretable mass spectrum was obtained (Table 2). Only low molecular weight $(\mathrm{m} / \mathrm{e}=506$ through 450$)$ porphyrins of the etio series were found.

More reliable data were obtained for Samples 63-2, 20-21 cm, 63-2, 44-52 cm, and 63-3, 142-144 cm. Mass spectra of the nickel and vanadyl porphyrins isolated from these samples are shown in Figures 1 through 6.

The nickel porphyrin fraction from $63-2,20-21 \mathrm{~cm}$ illustrates the severity of the thermal stress undergone (Figure 1); the etio series predominates with the mode at a mass of 492. Band widths (Table 3 ) are narrow ( $\sigma=$ 18 for DPEP series and 20 for the etio series). Only one molecular weight species above that of nickel DPEP was noted, although six members lower than DPEP were observed. In contrast, the vanadyl porphyrin fraction isolated from the same sample has three molecular weight species above DPEP as well as six with lower weights (Figure 2). Calculated band widths are correspondingly wider $(\sigma=25$ and 24 for the DPEP and etio series, respectively).

In Figure 3 is shown the mass spectrum of the nickel porphyrin fraction from Sample 368-63-2, $44-52 \mathrm{~cm}$. In this case, the DPEP series predominates (Table 3 ), a wider band width $(\sigma=23$ and 24) and two molecular weight species greater than nickel DPEP are observed. The envelope of the vanadyl porphyrin fraction (Figure 4) again contrasts with that of the nickel fraction: five members above vanadyl DPEP are present and band widths are very wide ( $\sigma=27$ and 30 for DPEP and etio, respectively).

A final comparison (Section 368-63-3) between nickel and vanadyl porphyrin fractions isolated from the same sediment sample is illustrated in Figures 5 and 6. Although the DPEP series predominates in both fractions, it is more dominant in the vanadyl porphyrin fraction with the etio series nearly absent (Figure 6) and band widths for both the DPEP and etio series relatively narrow $(\sigma=16$ and 20$)$. This mass distribution compares closely with those obtained for Early Cretaceous samples from the Angola and Cape basins (Baker et al., in press). However, in addition to molecular weight components characteristic of normal diagenesis, three high molecular weight members above vanadyl DPEP are present in small but observable amounts, indicating slightly greater thermal stress. Wider band widths ( $\sigma=22$ and 23) and four molecular weight numbers above C-32 are observed in the nickel porphyrin fraction (Figure 5).

In both Figures 3 and 5 the major nickel porphyrin peak is $\mathrm{m} / \mathrm{e}=518$, one methylene unit less than DPEP. However, the major vanadyl peak from the same extracts (Figures 4 and 6$)$ is that of vanadyl DPEP $(\mathrm{m} / \mathrm{e}$ $=541)$. Perhaps nickel DPEP $(\mathrm{m} / \mathrm{e}=532)$ degraded more rapidly, through loss of methylene units and/or etio series generation than vanadyl DPEP. Note that nickel porphyrins appear to "add" methylene groups more slowly than the vanadyl counterpart. And, as observed in 368-63-3, the vanadyl porphyrins retain a diagenetically younger profile in comparison with nickel porphyrins that have undergone the same amount of thermal stress.

Only nickel porphyrins were found in 368-63-4. The mode is equivalent to nickel DPEP $(\mathrm{m} / \mathrm{e}=532)$ and mass spectrometric parameters are comparable to geoporphyrins having undergone a mild thermal history.

\section{DISCUSSION}

As noted earlier, the discovery of the sill turned what otherwise would have been a rather prosaic sample site into a unique location which provided a focus of attention and interest for Leg 41 organic geochemistry. Sequences of reactants and products produced by the graded thermal treatment of the rather homogeneous black shale were thus available for analysis. These results permitted verification of organic matter maturation reaction pathways and even of reaction rates which were up to now only speculative.

The porphyrins, which are known to undergo a series of recognizable chemical changes with increasing thermal stress, provided us with a rather clear record of the events. At least four different types of reactions can occur when metalloporphyrins are subjected to severe thermal stress: (1) dealkylation; (2) isocyclic ring opening, i.e., conversion of DPEP series to etio series; (3) alkylation; and (4) thermal decomposition. The effect of increasing thermal stress on the progress of these reactions is illustrated in Table 4 and discussed below. 

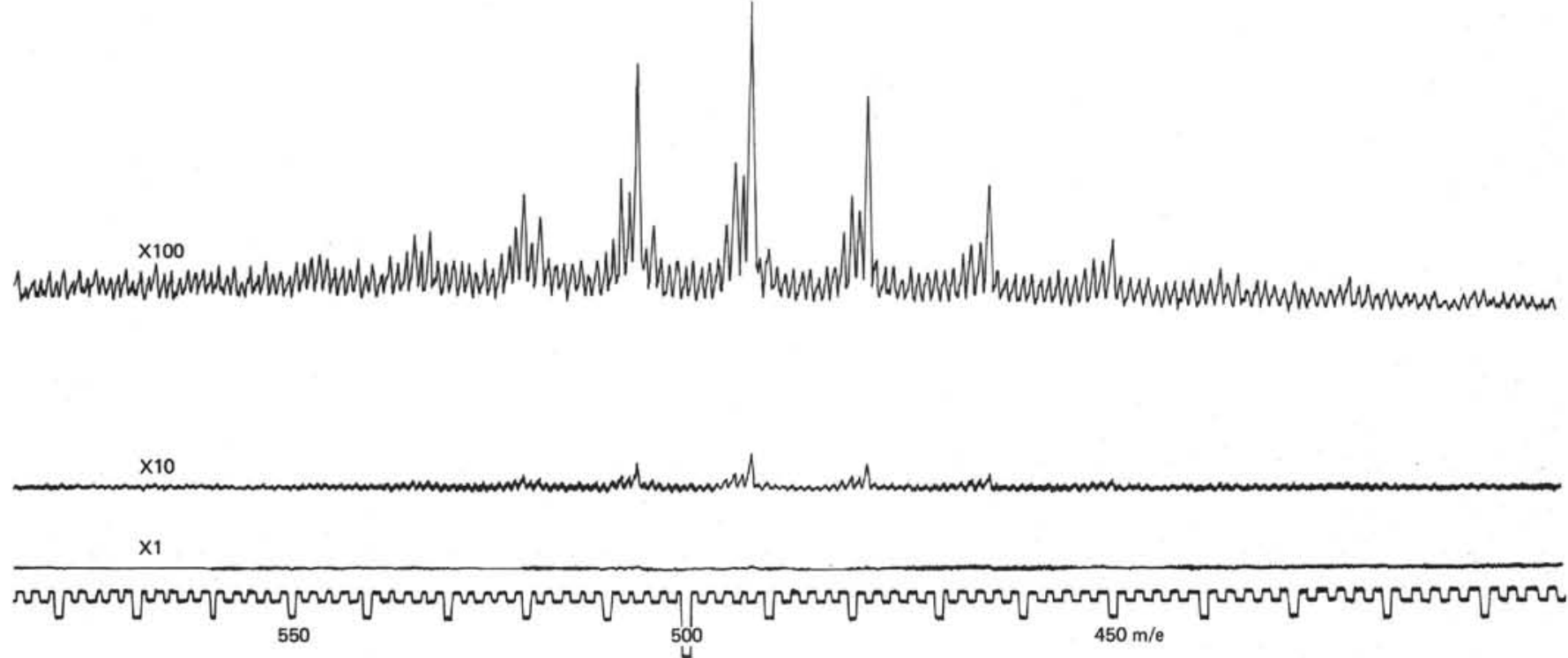

Figure 1. Partial $12 \mathrm{ev}$ mass spectrum of the nickel porphyrin fraction of the organic extract from $368-63-2,21-22 \mathrm{~cm}$. Source temperature, $270^{\circ} \mathrm{C}$, probe temperature $295^{\circ} \mathrm{C}$, four major spectral peaks are: m/e 506, normalized intensity = 77; $\mathrm{m} / \mathrm{e} 492$, normalized intensity $=100 ; \mathrm{m} / \mathrm{e} 478$, normalized intensity $=70 ;$ and $\mathrm{m} / \mathrm{e} 464$, normalized intensity $=34$.

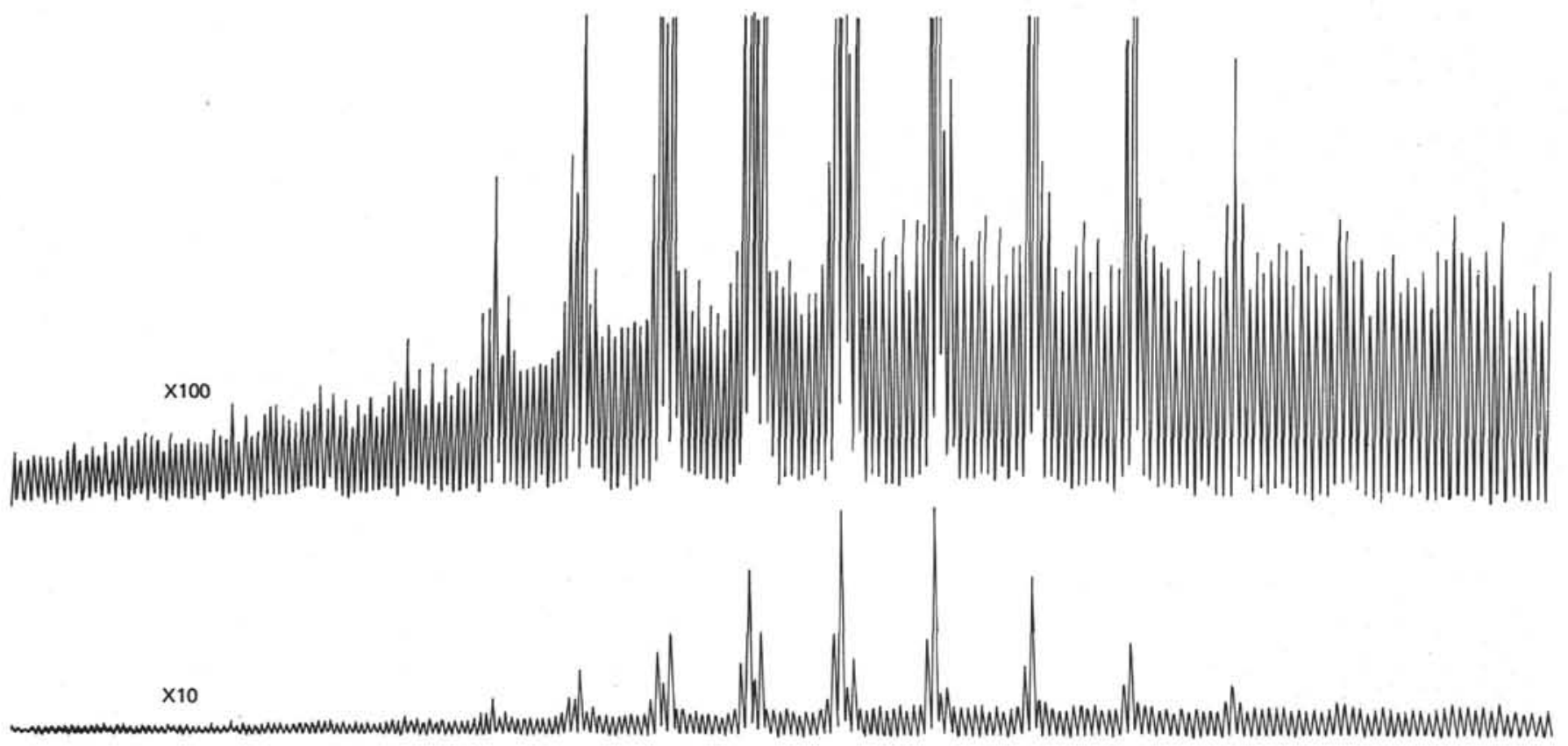

$\mathrm{x} 1$

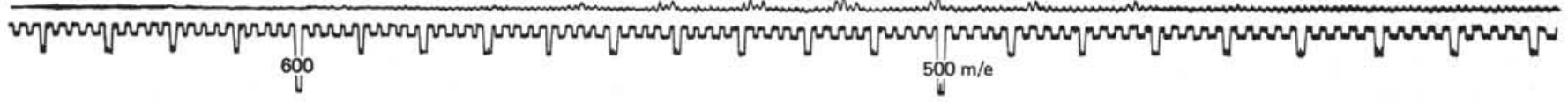

Figure 2. Partial $12 \mathrm{ev}$ mass spectrum of the vanadyl porphyrin fraction of the organic extract from 368-63-2, $20-21 \mathrm{~cm}$. Source and probe temperature $260^{\circ} \mathrm{C}$. Five major spectral peaks are: $\mathrm{m} / \mathrm{e} 541$, normalized intensity $=44 ; \mathrm{m} / \mathrm{e} 529$, normalized intensity $=72 ; \mathrm{m} / \mathrm{e} 515$, normalized intensity $=97 ; \mathrm{m} / \mathrm{e} \mathrm{501}$, normalized intensity $=100 ; \mathrm{m} / \mathrm{e} 487$, normalized intensity $=72 ;$ and $\mathrm{m} / \mathrm{e} 473$, normalized intensity $=44$. 


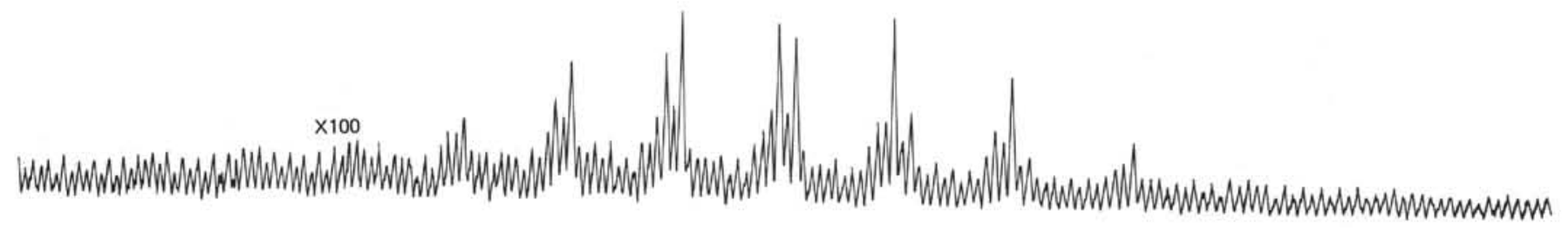

$\times 10$

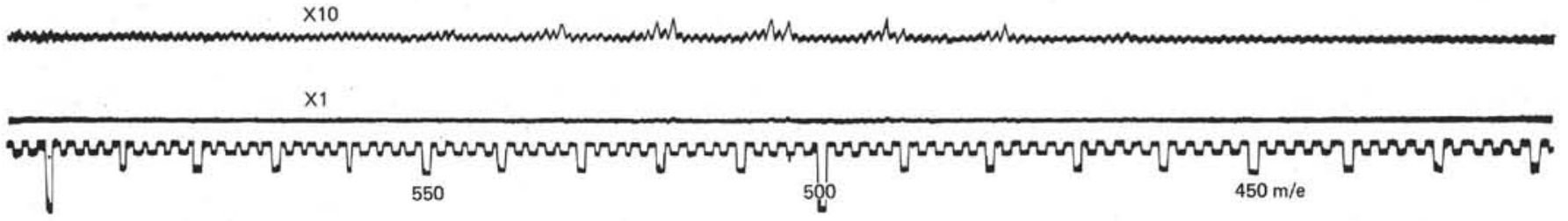

Figure 3. Partial $12 \mathrm{ev}$ mass spectrum of the nickel porphyrin fraction of the organic extract from $368-63-2,44-52 \mathrm{~cm}$. Source temperature $290^{\circ} \mathrm{C}$ and probe temperature $285^{\circ} \mathrm{C}$. Five major spectral peaks are: $\mathrm{m} / \mathrm{e} 532$, normalized intensity

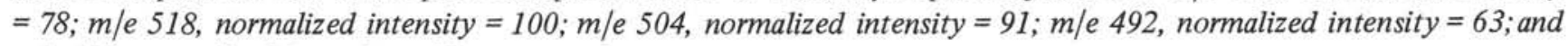
$m / e 478$, normalized intensity $=53$.

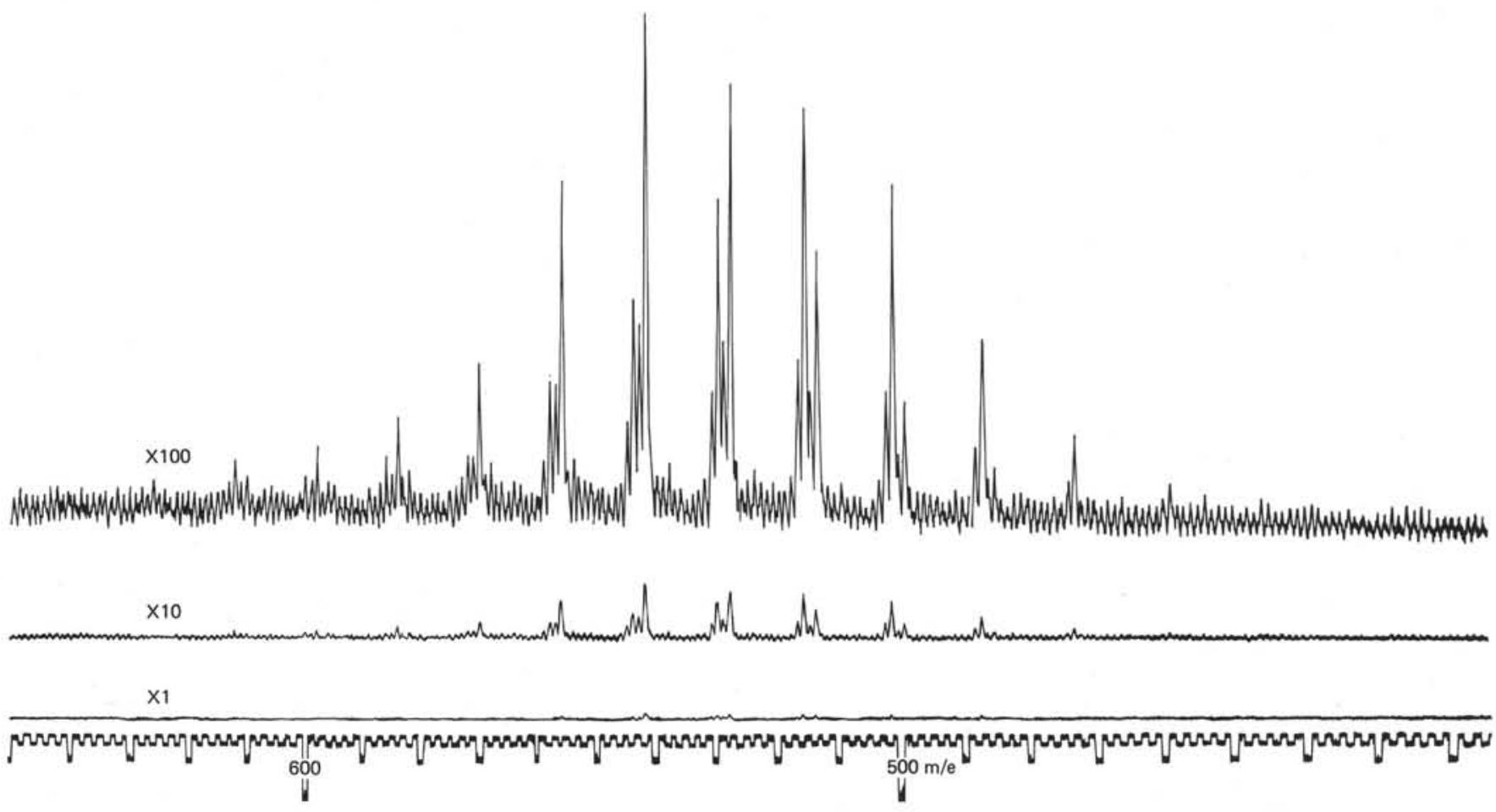

Figure 4. Partial $12 \mathrm{ev}$ mass spectrum of the vanadyl porphyrin fraction of the organic extract from $368-63-2,44-52 \mathrm{~cm}$. Source and probe temperature $250^{\circ} \mathrm{C}$. Five major spectral peaks are: $\mathrm{m} / \mathrm{e} 555$, normalized intensity $=66 ; \mathrm{m} / \mathrm{e} 541$, normal-

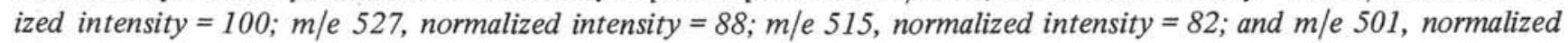
intensity $=68$.

\section{Dealkylation}

One measure of dealkylation is the average molecular weight of the porphyrins and the mode of the molecular weight envelope of the metalloporphyrins is seen to move to lower values as the sill is approached (Table 4, Column 1). In the nickel etio series a decrease from C$30(\mathrm{~m} / \mathrm{e}=506)$ at 7.4 meters from the sill to C-27 (m/e $=464)$ at 3.7 meters is observed. Paralleling this change, the mode of the vanadyl etio series shifts from C-32 $(\mathrm{m} / \mathrm{e}=543)$ to $\mathrm{C}-29(\mathrm{~m} / \mathrm{e}=501)$ as the distance to the sill is decreased from 7.4 meters to 4.7 meters. At 2.7 meters from the sill so little pigment survived that no molecular weight measurements could be made; however, extrapolation of the data in Columns I, II, and III, Table 4 would suggest that the residue would be a highly dealkylated nickel porphyrin (possibly as low as C-24). 


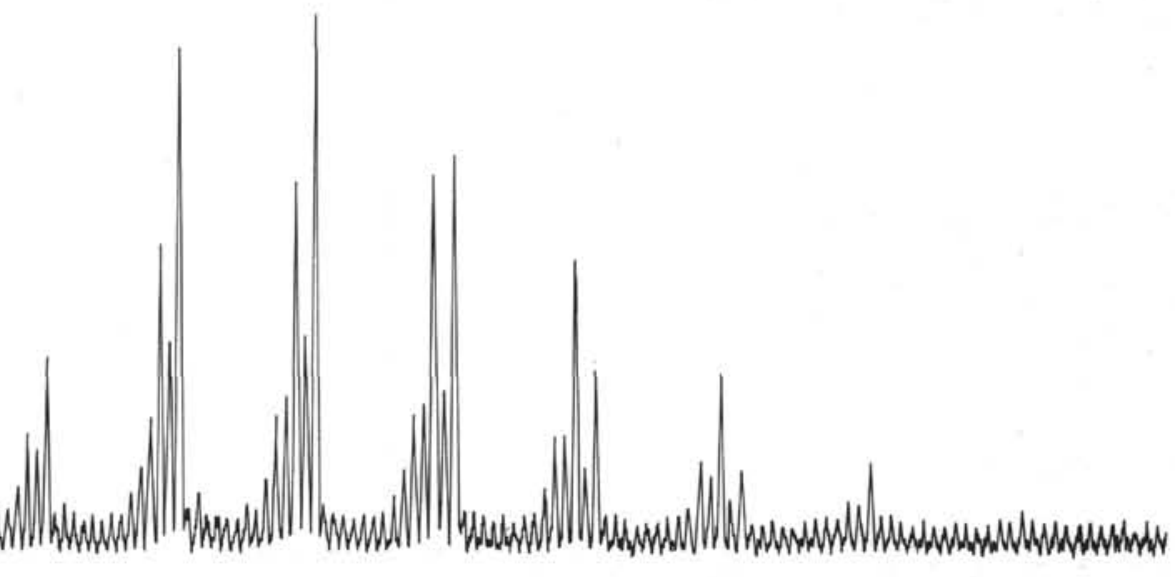

X10

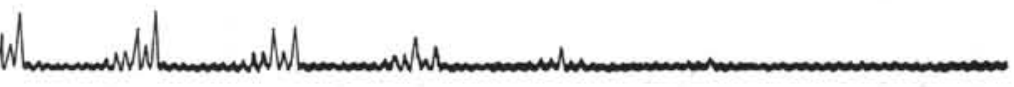

$\mathrm{x} 1$

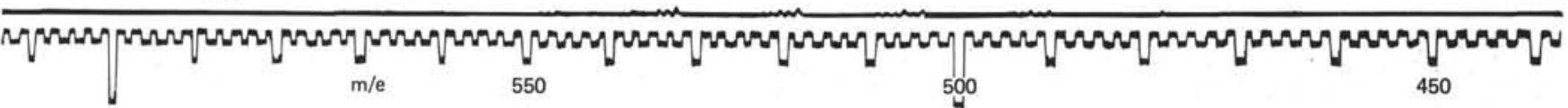

Figure 5. Partial 12 ev mass spectrum of the nickel porphyrin fraction of the organic extract from $368-63-3,141-144 \mathrm{~cm}$. Source and probe temperature $275^{\circ} \mathrm{C}$. Three major spectral peaks are: $\mathrm{m} / \mathrm{e} 532$, normalized intensity $=85 ; \mathrm{m} / \mathrm{e} 518$, normalized intensity $=100$; and $\mathrm{m} / \mathrm{e} 504$, normalized intensity $=59$.

$\times 100$

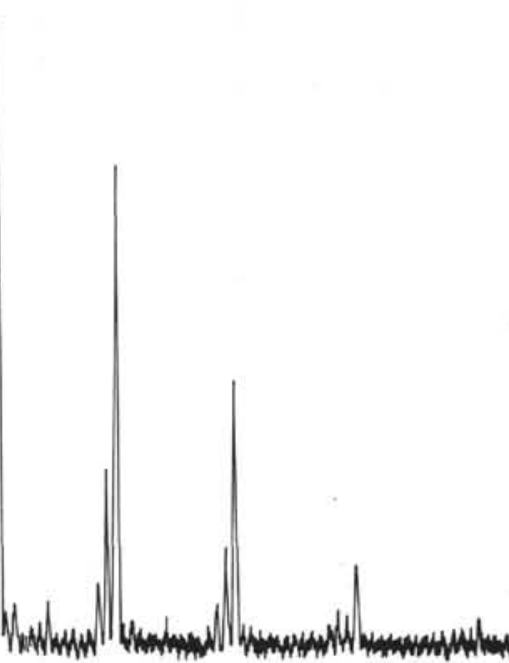

$\times 10$

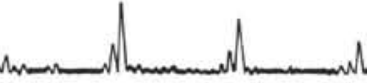

$\mathrm{X} 1$

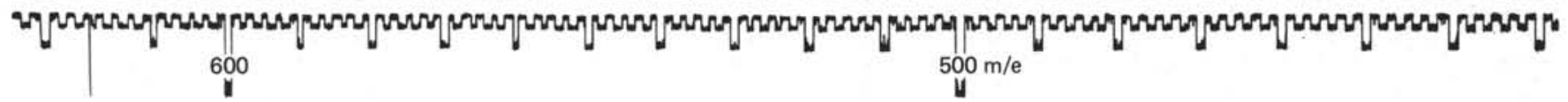

Figure 6. Partial $12 \mathrm{ev}$ mass spectrum of the vanadyl porphyrin fraction of the organic extract from $368-63-3,141-144 \mathrm{~cm}$. Source and probe temperature $240^{\circ} \mathrm{C}$. Three major spectral peaks are: $\mathrm{m} / \mathrm{e} 541$, normalized intensity $=100 ; \mathrm{m} / \mathrm{e} 527$, normalized intensity $=82$; and $\mathrm{m} / \mathrm{e} 513$, normalized intensity $=36$. 
A variety of dealkylation processes has been postulated including devinylation and $\beta$-cleavage decarboxylation which can proceed under mild thermal stress and transalkylation of unactivated alkyl substitutents which only occurs when stresses near the molecular decomposition point are imposed. The latter case apparently obtains near the sill while the former conditions seem to account for the observations beyond 8-10 meters distant.

\section{Etio Series Generation}

That the main source of the etio series in fossil porphyrins is thermal opening of the DPEP isocyclic ring is now clear (Baker et al., 1967; Didyk et al., 1975). This reaction is illustrated in Figure 7. In Table 4, Column II the changes, as the sill is approached, in the $a / \beta$ ratio of the visible spectral peaks of the nickel porphyrins are listed and illustrative spectra are shown in Figure 8. An $a / \beta$ ratio of 2.3 is indicative of a DPEP/etio ratio of ca. 2 , based on $a / \beta$ ratios of nickel deoxophylloerythroetioporphyrin and nickel etioporphyrin III of 2.0 and 3.0, respectively (Baker et al., 1968). *

A linear change of the $a / \beta$ ratio from 2.3 at a distance to 4.4 in close proximity to the sill is indicative of partial to total conversion to the etio series coincident with increasing dealkylation. In Column II$\mathrm{b}$ is shown the DPEP/etio as determined mass spectrometrically from the nickel porphyrins. No nickel porphyrin of the DPEP series survived closer than 4 meters from the sill. The two data sets are consistent with the exception of the mass spectral data at 7 and 8 meters; in 368-63-3 determination of the mass spectral DPEP/etio ratio was made difficult by the divergent volatilities of the porphyrins of the two series.

\section{Alkylation}

A parameter designed to indicate the degree of alkylation that has occurred has been defined as the alkylation index $=\Sigma[($ carbon number -32$) \mathrm{I}] / \Sigma \mathrm{I}$, where $I$ is the mass spectral peak intensity at a given $\mathrm{m} / \mathrm{e}$. In Table 4, Columns III-a and -b, the alkylation indices for the suite of nickel and vanadyl porphyrins are shown. The values range from 0.08 to 0.3 for the nickel porphyrins and from 0.1 to 0.7 for the vanadyl porphyrins. For comparison, a highly alkylated petroporphyrin of the DPEP series such as Boscan

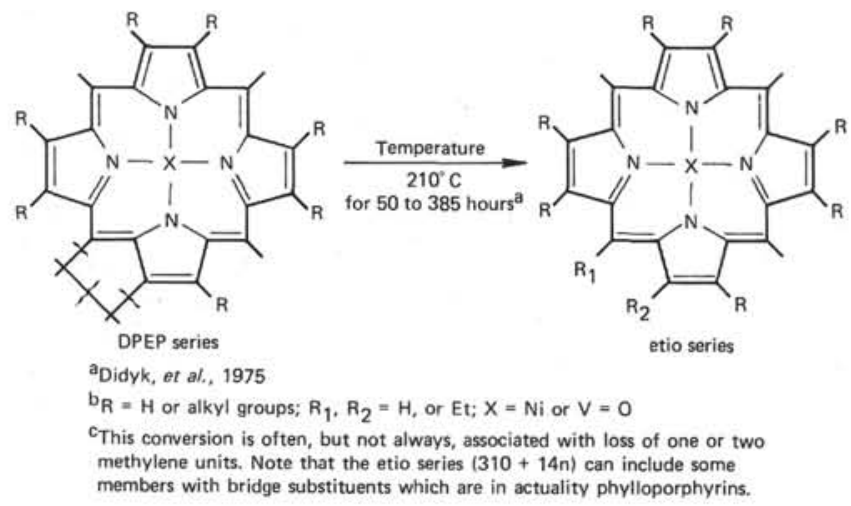

Figure 7. Schematic representation of isocylic ring opening and etio series generation.

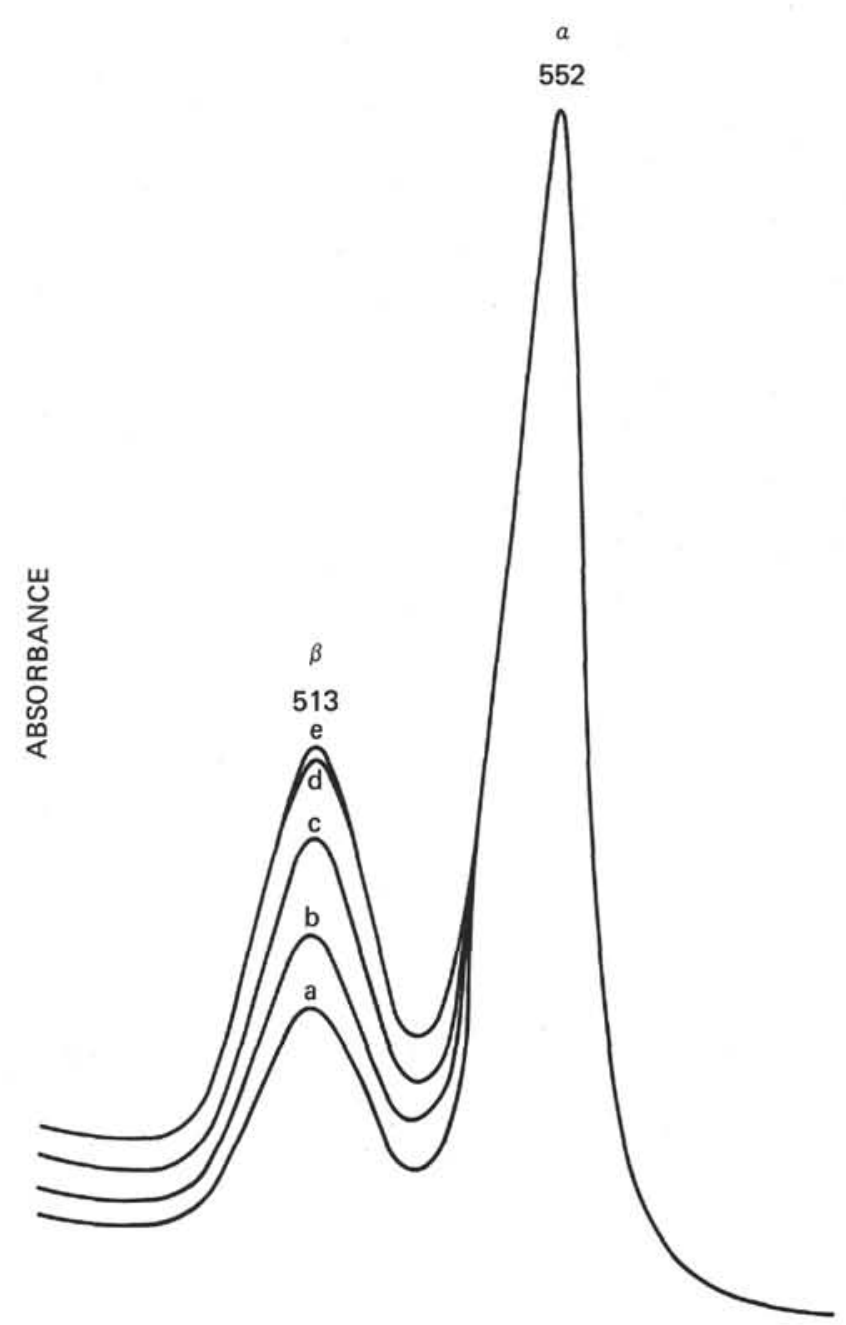

Figure 8. Visible spectra $(470-600 \mathrm{~nm})$ of nickel porphyrin fractions of the organic extract from core samples (a) $368-63-1,68-72 \mathrm{~cm}$, (b) $63-2,20-21 \mathrm{~cm}$, (c) $63-2,44-52$ $\mathrm{cm}$, (d) 63-3, 141-144 cm, and (e) 63-4, 90-98 cm. The $\alpha$ band was adjusted by using the concentration range on the ACTA CIII to produce a constant peak height of 1.0 Abs.

(Cretaceous) with six series members above C-32 has an alkylation index of 0.97 . In contrast, Belridge (Pliocene) petroporphyrin of the DPEP series has a value of 0.10 with only 2 series members above C-32, and Gilsonite (Eocene) DPEP series petroporphyrins have a value of 0.44 (Baker et al., 1967. Normally, porphyrins found in marine sediments (such as those in Core 361-41) are nonalkylated and have a value of zero (Baker et al., in press).

The data strongly support prior suggestions that alkylation is related to thermal treatment and that vanadyl chelation promotes alkylation relative to nickel chelation (compare 0.7 and 0.3 for 368-63-2).

\section{Thermal Decomposition}

Erratic thermal degradation of nickel versus vanadyl porphyrins can be illustrated by the relative abundance of each. In Table 4, Column IV the ratios of concentrations of these pigments are shown. Thermal decomposition of vanadyl and nickel petroporphyrins has 
TABLE 4

Selected Characteristics of Pigments, Vitrinite, and n-Paraffins From Site 368 Late Cretaceous Cores

\begin{tabular}{|c|c|c|c|c|c|c|c|c|c|c|}
\hline \multirow{4}{*}{$\begin{array}{c}\text { Sample } \\
\text { (Interval in } \mathrm{cm} \text { ) }\end{array}$} & \multirow{4}{*}{$\begin{array}{c}\text { Distance } \\
\text { Below Sill (m) }\end{array}$} & \multicolumn{2}{|c|}{ I } & \multicolumn{2}{|c|}{ II } & \multicolumn{2}{|c|}{ III } & \multirow{4}{*}{$\begin{array}{c}\text { IV } \\
\mathrm{Ni} / \mathrm{V}=\mathrm{O}\end{array}$} & \multirow{4}{*}{$\begin{array}{r}\mathrm{V} \\
R_{O}\end{array}$} & \multirow{4}{*}{$\begin{array}{l}\text { VI } \\
\text { CPI }\end{array}$} \\
\hline & & a & $\mathrm{b}$ & a & b & a & b & & & \\
\hline & & \multicolumn{2}{|c|}{$\begin{array}{l}\text { Etio Series } \\
\text { mode }(\mathrm{m} / \mathrm{e})\end{array}$} & \multirow{2}{*}{$\begin{array}{c}\text { Etio Serie } \\
\alpha / \beta\end{array}$} & \multirow{2}{*}{$\begin{array}{l}\text { Generation } \\
\text { DPEP/etio }\end{array}$} & \multicolumn{2}{|c|}{ Alkylation Index } & & & \\
\hline & & $\mathrm{Ni}$ & $\mathrm{V}=0$ & & & $\mathrm{Ni}$ & $\mathrm{V}=0$ & & & \\
\hline $\begin{array}{l}368-62-3 \\
72-80\end{array}$ & 0.71 & & & & & & & & * & 1.05 \\
\hline $\begin{array}{l}368-62-4 \\
44-52\end{array}$ & 1.93 & & & & & & & & 2.60 & 1.15 \\
\hline $\begin{array}{l}368-62-4 \\
118-126\end{array}$ & 2.67 & & & & & & & 0.5 & 1.44 & 1.28 \\
\hline $\begin{array}{l}368-63-1, \\
68-76\end{array}$ & 3.67 & 467 & & 4.4 & 0 & & & 1.5 & & \\
\hline $\begin{array}{l}368-63-2, \\
20-21\end{array}$ & 4.69 & 492 & 501 & 3.6 & 0.5 & 0.1 & 0.5 & 0.7 & & \\
\hline $\begin{array}{l}368-63-2 \\
44-52\end{array}$ & 4.93 & 492 & 515 & 2.9 & 1.5 & 0.3 & 0.7 & 0.7 & & \\
\hline $\begin{array}{l}368-63-3 \\
141-144\end{array}$ & 7.41 & 506 & 543 & 2.6 & 3.5 & 0.3 & 0.1 & 1.5 & 1.05 & 1.29 \\
\hline $\begin{array}{l}368-63-4, \\
90-98\end{array}$ & 8.39 & 492 & & 2.3 & 2.1 & 0.08 & & & 0.85 & 1.36 \\
\hline
\end{tabular}

Note: I. m/e of most intense mass spectral peak; from Table 1 . II. $\alpha / \beta=$ ratio of 552 to $513 \mathrm{~nm}$ visible spectral bands after baseline correction, see Figure 8. DPEP/etio $=\Sigma$ IDPEP $/ \Sigma$ I etio, see Table 3. III. Alkylation Index $($ A.I. $)=$ $\Sigma[($ carbon number -32$) \mathrm{I}] / \Sigma \mathrm{I}$ where intensities (I) are the mass spectral peak heights from Table 2 . IV. $\mathrm{Ni} / \mathrm{V}=\mathrm{O}=$ yield of nickel porphyrin $(\mu \mathrm{g} / \mathrm{g}) /$ yield of vanadyl porphyrin $(\mu \mathrm{g} / \mathrm{g})$ from Table $1 . \mathrm{V} \cdot R_{O}=$ vitrinite reflectance; these data provided by W. G. Dow of Superior Oil Co. VI. CPI = carbon preference index (Cooper and Bray, 1963). These data provided by W. G. Dow of Superior Oil Co. *Insufficient uncoked vitrinite for analysis.

been experimentally found to be a first-order process with a rate constant for the vanadyl chelate about 1.7 times that of the nickel chelate (Rosscup and Bowman, 1967). Their data indicate that nickel porphyrins should withstand greater thermal stress than vanadyl porphyrins. Following this reasoning, therefore, one would expect that relatively more nickel porphyrins should survive closer to the sill, resulting in a higher $\mathrm{Ni} / \mathrm{V}=\mathrm{O}$ ratio at this point. However, our data do not indicate such a straightforward fate for metalloporphyrins. (Note the erratic $\mathrm{Ni} / \mathrm{V}=\mathrm{O}$ ratios). An alternative explanation of the $\mathrm{Ni} / \mathrm{V}=\mathrm{O}$ ratios observed in these particular samples can be advanced. An overview of the Late Cretaceous data from Site 368 shows that normal porphyrin diagenesis has progressed to the nickel DPEP porphyrin stage at $368-58$. At greater depth the normal process is interrupted by high thermal stress with concomitant formation of vanadyl porphyrins and decomposition of the native nickel porphyrins. Further below the sill (368-63-4) only slightly altered nickel porphyrins, again predominantly of the DPEP-type, are observed. The occurrence of vanadyl porphyrins in only highly thermally stressed sediment samples (368-62-4 to 368-63-3) may suggest that their formation is related to the thermal input provided by igneous intrusion.
It is important to note that the vanadyl porphyrins found in this environment have two features which distinguish them from those found in other marine sediments with normal thermal gradients (Baker et al., in press). Observed here for the first time in sediments were vanadyl porphyrins of the etio series, a feature reminiscent of petroporphyrins. A second distinguishing feature is the presence of alkylated porphyrins of both the DPEP and etio series. Taken together, these observations strongly support the above suggestion concerning the mode of formation of the vanadyl porphyrins. We further note the resemblance of these unique groups of marine geoporphyrins to the ubiquitous petroporphyrins.

The source of the vanadyl porphyrins is not clear, but vanadium release from kerogen during diagenesis appears a reasonable speculation at this time.

Another indicator of organic matter maturation is vitrinite reflectance $\left(R_{o}\right) . R_{o}$ values for immature sediments range from 0.2 to 0.4 , while values for petroleum-generating sediments are 0.6 to 1.0 ; higher values $\left(R_{o}=2.0\right)$ are indicative of gas generation. Thus, an $R_{o}=0.24$ for Core $367-19$ reconfirms its relatively immature nature.

Five samples from Site 368 (Table 4, Column V) reflect the effect of contact metamorphism associated 
with the overlying diabase sill. Two samples within 2 meters of the sill contact contain abundant natural coke and one did not have sufficient uncoked vitrinite for analysis. Because of its finely microcrystalline structure, coke cannot be used to measure maturity by reflectance techniques. The other four samples systematically decline in reflectivity below the sill, but all have experienced some contact metamorphism.

Carbon preference index (CPI) is also indicative of thermal maturation. A relatively high CPI value of 1.32 for 367-19 contrasts with systematic decrease from 1.36 to 1.05 as the sill is approached (Table 4, Column VI).

\section{Intrusions, Diagenesis, and Temperatures}

The extent of the diagenetic reactions in the vicinity of the sill has been discussed in detail. Now consider the converse; can the temperature excursion necessary to produce the observed reactions be estimated? In principle the answer is affirmative. Using the data from Table 4, conventional knowledge of reaction kinetics, principles of igneous geology and intuition, a temperature profile in the region of the sill has been constructed and is shown in Figure 9. In constructing the profile, it was necessary to make a number of assumptions of varying quality which in turn reflect as ranges of uncertainty in the "most likely" profile. The most likely profile is shown as a curve with the range of uncertainty superimposed as a shaded band. However, for reasons which will be discussed, it may be that the actual case would be more accurately represented by two lines intersecting at a point about 3.5 meters from the sill. The data interpretation and important assumptions are now described.

Sample 368-62-4, 118-126 cm, 2.67 meters below the sill, contained a trace of extractable pigment $(0.2$ and $0.4 \mu \mathrm{g} / \mathrm{g}$ of nickel and vanadyl porphyrin, respectively), while a sample some $60 \mathrm{~cm}$ closer to the sill was devoid of pigment presumably because it was overheated and destroyed. Conversely, the sediments slightly further from the sill contained significantly greater amounts of extractable pigment. Based on analysis and the data of Rosscup and Bowman (1967) the maximum momentary temperature limit for this location is placed at $350^{\circ} \mathrm{C}$. According to the data of Rosscup and Bowman, at $373^{\circ} \mathrm{C}$ the half-life of nickel petroporphyrin is $15 \mathrm{hr}$ and that of vanadyl petroporphyrin $8.5 \mathrm{hr}$.

Assuming, as is usually done, that 10 half-lives will reduce the concentration below detectable limits, at $350^{\circ} \mathrm{C}$ the porphyrin at this location would have been destroyed in a matter of days and certainly temperature near the maximum persisted longer than days. To make an estimate of the minimum temperature some insight into the time-temperature profile is necessary and some assumptions are required concerning the rate at which crystallization and cooling of the sill took place. Daly (1933) gives estimates for magma crystallization of 3 and $300 \mathrm{yr}$ for thicknesses of 10 and 100 meters upon exposure to air.

Making the assumption that the reaction rate decreases by a factor of two for each $10^{\circ} \mathrm{C}$ reduction in temperature, at $170^{\circ} \mathrm{C}$ approximately $50,000 \mathrm{yr}$ would be required to destroy the pigment (e.g., the rate changes by a factor of $\left.2^{17} \cong 1.3 \times 10^{5}\right)$. Thus, a

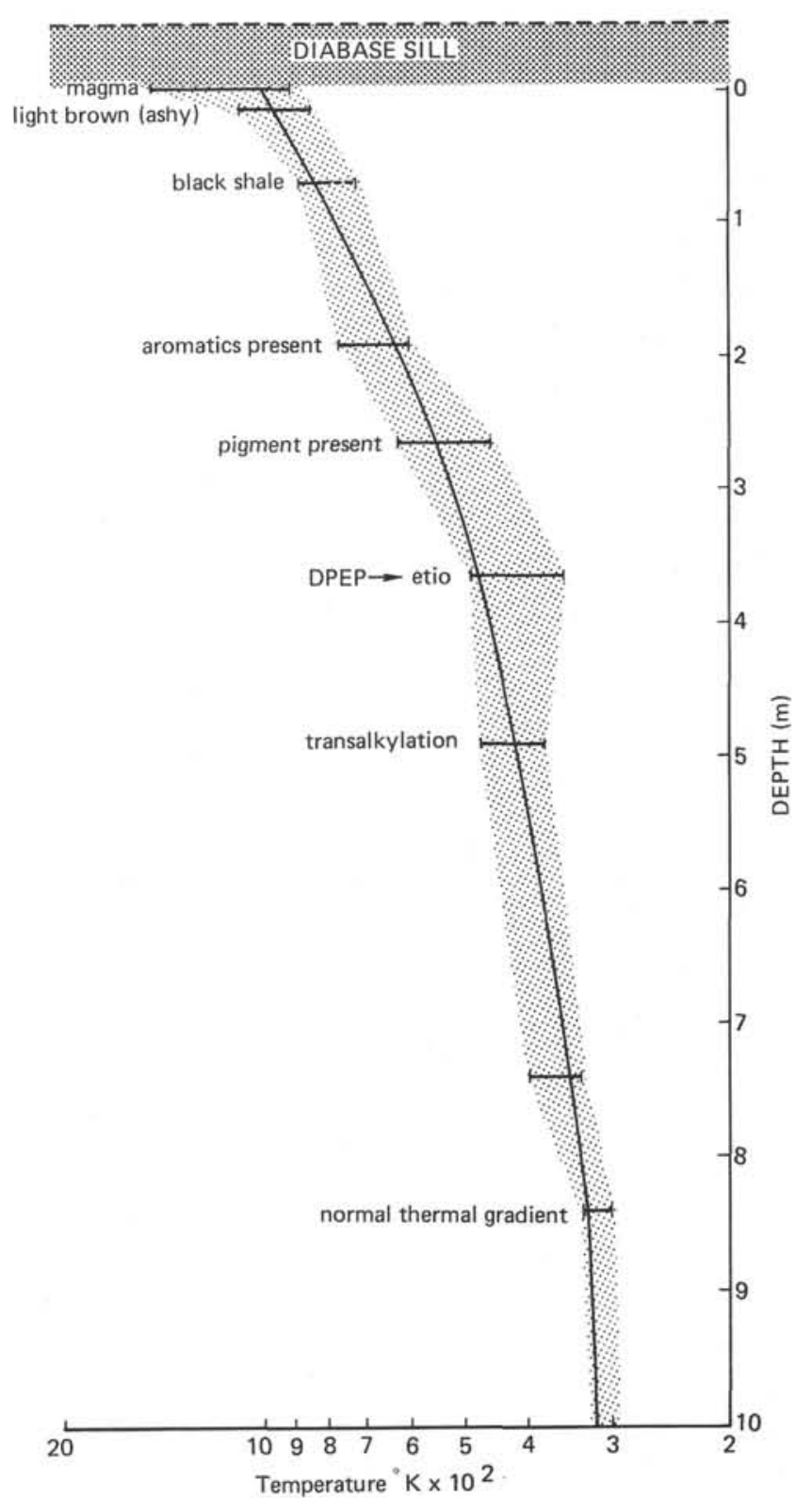

Figure 9. Temperature versus distance from diabase sill, Site 368.

minimum temperature is set and a range determined. Since it seems very unlikely that the temperature remained elevated for $50,000 \mathrm{yr}$, the best estimate of maximum temperature at this point is $555^{\circ} \mathrm{K}\left(282^{\circ} \mathrm{C}\right)$.

The maximum transient temperature at the points further from the sill are determinable by yet another characteristic of the porphyrins, namely opening of the isocyclic ring of DPEP to form porphyrins of the etio series (Figure 7). Didyk et al. (1975) performed experiments which showed the DPEP to etio conversion approximately $1 / 2$ completed in $150 \mathrm{hr}$, at $483^{\circ} \mathrm{K}\left(210^{\circ} \mathrm{C}\right)$. Thus, two points are established: (1) the most probable temperature maximum at a point 4.69 (Section 368-63-2) meters from the sill where the DPEP/etio ratio equals 0.5 is $423^{\circ} \mathrm{K}$ and (2) the temperature at this point could not have exceeded $483^{\circ} \mathrm{K}$. 
Making the assumption that at 3.67 meters (368-631) the concentration of the DPEP series has been decreased to just below the detectable level, the maximum, minimum, and most probable temperatures are 485,350 , and $472^{\circ} \mathrm{K}$.

At 1.93 meters from the sill the maximum proportion of aromatic compounds were found, but no pigment was present. The first observation defines the upper temperature limit at about $773^{\circ} \mathrm{K}$ and the second, the minimum at $600^{\circ} \mathrm{K}$.

Samples taken within 2 meters of the sill varied from black to light brown. The black samples contained some extractable organic material and coke. In the light brown sample essentially all of the vitrinite was coked and no organic material was detected. On this basis temperature limits of $880^{\circ}$ and $1060^{\circ} \mathrm{K}$ are estimated. The upper limit of the magma was set at the usual Geology textbook temperature of $1473^{\circ} \mathrm{K}\left(1200^{\circ} \mathrm{C}\right)$. The actual temperature at the contact was likely several hundred degrees less, with a most probable temperature near $1000^{\circ} \mathrm{K}$.

Sample 368-63-4 taken at 8.4 meters from the sill contains no vanadyl porphyrin and has an alkylation index of 0.08 . These are at about the maturation expected for a Cretaceous sediment at a 1000 meters depth of burial. A gradient of $4^{\circ} / 100$ meters gives a probable temperature of $313^{\circ} \mathrm{K}$ in the absence of the sill. The above indices of maturation indicate that an excursion from this temperature at this point was limited and transient. Customarily, igneous bodies affect organic material in intruded sediments to a distance about twice their thicknesses which would be about 27 meters. It would appear that, in this case, significant changes in the organic materials were restricted to a region considerably narrower.

\section{ACKNOWLEDGMENTS}

This research was supported by the Oceanography Section of the National Science Foundation, Grants GA-43359X and DES-74-12438 AO1.

The authors greatly appreciate the source rock evaluation, including hydrocarbon characterization and vitrinite reflectance data, generously provided by Wallace G. Dow of the Superior Oil Company.

Much thanks to Dr. J. Graham Rankin for special efforts in collecting samples in proximity of the diabase sill.

\section{REFERENCES}

Baker, E.W., 1969. Porphyrins. In Ewing, M., Worzel, J.L., et al., Initial Reports of the Deep Sea Drilling Project,
Volume 1: Washington (U.S. Government Printing Office), p. 498.

Baker, E.W., Corwin, A.H., Klesper, E., and Wei, P.E., 1968. Deoxophylloerythroetioporphyrin: J. Org. Chem., v. 33, p. 3144.

Baker, E.W., Palmer, S.E., and Huang, W.Y., in press. Chlorin and porphyrin geochemistry of DSDP Leg 40 sediments. In Bolli, H.M., Ryan, W.B.F., et al., Initial Reports of the Deep Sea Drilling Project, Volume 40: Washington (U.S. Government Printing Office). , in press. Miocene and Cretaceous tetrapyrrole pigments from Leg 44, Site 391. In Benson, W.E., Sheridan, R.E., et al., Initial Reports of the Deep Sea Drilling Project, Volume 44: Washington (U.S. Government Printing Office).

Baker, E.W., Palmer, S.E., and Parrish, K.L., 1978. Tetrapyrrole Pigments in DSDP Leg 38 Sediments. In Talwani, M., Udintsev, G., et al., Initial Reports of the Deep Sea Drilling Project, Volume 38: Washington (U.S. Government Printing Office), p. 785.

Baker, E.W. and Smith, G.D., 1973. Pleistocene changes in chlorophyll pigments. In Tissot, B. and Bienner, F. (Eds.), Adv. in organic geochemistry: Paris (Editors Technip), p. 649 .

1975. Chlorophyll derivatives in DSDP Leg 31 Sediments. In Ingle, J.C., Karig, D.E., et al., Initial Reports of the Deep Sea Drilling Project, Volume 31: Washington (U.S. Government Printing Office), p. 629.

Baker, E.W., Yen, T.F., Dickie, J.P., Rhodes, R.E., and Clark, L.F., 1967. Mass spectrometry of porphyrins II: Characterization of petroporphyrins: J. Am. Chem. Soc., v. 89, p. 3631 .

Bonnett, R., Brewer, P., Noro, K., and Noro, T., 1972. On the origin of petroporphyrin homologues: The transalkylation of vanadyl octa-alkyl porphyrins: Chem. Comm., v. 289, p. 562.

Cooper, J.E. and Bray, E.E., 1963. A postulated role of fatty acids in petroleum formation: Geochim. Cosmochim. Acta, v. 27, p. 1113.

Daly, R.A., 1933. Igneous rocks and the depths of the earth: New York (McGraw-Hill Book Company, Inc.), p. 63.

Didyk, B.M., Alturki, Y.I.A., Pillinger, C.T., and Eglinton, G., 1975. Petroporphyrins as indicators of geothermal maturation: Nature, v. 256, p. 563.

Rosscup, R.J. and Bowman, D.H., 1967. Thermal stabilities of vanadium and nickel petroporphyrins: Preprints, Div. Pet. Chem., Am. Chem. Soc., v. 12, p. 77.

Smith, G.D. and Baker, E.W., 1974. Chlorophyll derivatives in DSDP Leg 22 sediments. In von der Borch, C.C., Sclater, J.G., et al., Initial Reports of the Deep Sea Drilling Project, Volume 22: Washington (U.S. Government Printing Office), p. 677. 